\title{
Applying new innovative market research methods in the innovation process of new products
}

\author{
T. GÁL, M. SoÓs, Z. SZAKÁLY \\ University of Debrecen, Faculty of Economics and Business, Institute of Applied Economics, \\ gal.timea@econ.unideb.hu \\ University of Debrecen, Faculty of Economics and Business, Institute of Marketing and Commerce, \\ soos.mihaly@econ.unideb.hu \\ University of Debrecen, Faculty of Economics and Business, Institute of Marketing and Commerce, \\ szakaly.zoltan@econ.unideb.hu
}

Abstract. The innovation environment has changed a lot in the recent years, companies and their enterprises concentrating on product- and process innovation have undergone a lot of changes. According to GUPTA et al. (1986) product innovation is a multidisciplinary process. Although, all functional interfaces are important in the product development process, the research and development - marketing interface is one of the most difficult one. In the last two decades the incredibly fast penetration of the internet has more and more effects on the consumer attitudes. It encourages market researchers to apply such methods by which they could get as close as to the consumers to know their attitudes without taking them out of their natural habitat. In this study our aim is to concentrate on the first phase of the product innovation, which is the exploration of insights and attitudes. In this phase we can use the classical, conventional market research techniques if we want to get primary data, such as focus group interviews, questionnaires, in-depth interviews, but there are new methods as well. One of such novel methods is netnography. The biggest advantage of this research method is that the researcher can observe the consumer groups' state of mind and decision-making mechanisms through publicly available communication sources in their natural environment. In this study it will be analysed how the directions of netnographic researches have changed by the dynamic changes of the internet. Besides, online participants' attitudes towards healthconscious nutrition are analysed in practice. As a result of this study, special groups could be identified, which can provide a new perspective for the companies operating in this field beside the classical segmentation techniques. These groups can be the ones which draw up latent market requirements, and thus, helping the companies' innovation processes.

\section{Introduction}

The definition of innovation has been defined by several researchers in various ways. Behind its continuous development the ceaseless change of economic environment and the market is standing primarily, which has made the innovation process even more difficult [21].

ZALTMAN et al. (1973) stated that the development and diffusion of innovations can be seen as a process composed of several phases. Each phase is characterized by different types of decisions and problems of coordination as well as by different patterns of communication. MYERS and MARQUIS 
(1969) proposed a three-step innovation process: idea development (the generation of a design concept), problem solving (technical efforts and problem solving in developing the proposed idea), and implementation (pilot production, inter area coordination).

The innovation environment has changed a lot in the recent years, companies and their enterprises concentrating on product- and process innovation have undergone a lot of changes. Innovation is not an internal secret issue of the companies (closed innovation), but a result of cooperation with many factors and participants (open innovation). The success of innovation is determined by the fact how well it can manage its contacts and cooperation in this process [19]. Many empirical research have proved that the participation of users is essential in the innovation process, since a company does its innovation activity in cooperation with other companies, suppliers, processors and merchants, and research institutes [6].

According to GUPTA et al. (1986) product innovation is a multidisciplinary process. Although, all functional interfaces are important in the product development process, the research and development - marketing interface is one of the most difficult one.

Figure 1. shows the five-stage process of innovation in our interpretation. In order to execute an efficient innovation process it is extremely important to assess the market demand. Factors presented in Figure 1. provide assistance to create a new product or service from the idea to the market launch which are optimized for the consumers. An advantage of this is that we can meet some latent market demand with the created product or service, on the other hand later it does not have to be modified according to the consumers' expectations afterwards.

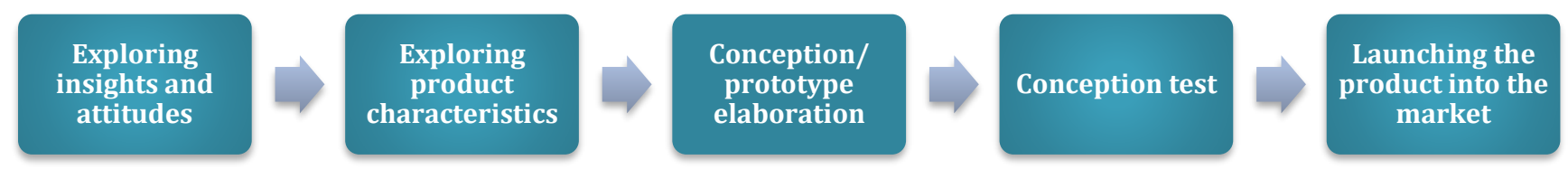

Figure 1. Stage of the innovation process.

(Source: own compilation, 2017)

In the first phase, besides exploring insights and attitudes, we can measure the word use, beliefs and misbeliefs of the consumers which are essential later for the successful marketing communication activities and the proper positioning.

As a next step, the stress is on forming the characteristics of the product or service. In this phase we can determine the parameters of the product or service to be created by both qualitative and quantitative methods which can be tested in the further phases. During the test period it is practical to use such methods in which not only researchers and consumers can participate but corporate representatives and even suppliers as well.

After testing the ready-made conception and its communication, in the market launch phase the main aim is to reach the innovator consumer group and influence them to buy the product or service. At this point spokesmen must be found who will have a positive word-of-mouth campaign if they are satisfied 
and they will have an effect on the crowd of consumers. By this process we can have an innovation totally optimized for consumers, and thus, the market launch and the reach of the growth phase of product life cycle can be directed.

In this study our aim is to concentrate on the first phase, which is the exploration of insights and attitudes. In this phase we can use the classical, conventional market research techniques if we want to get primary data, such as focus group interviews, questionnaires, in-depth interviews, but there are new methods as well. One of such novel methods is netnography.

\section{Netnography}

During ethnographic research the researcher examines a given group's habits, values, beliefs, patterns. The researcher has to be present for a longer time in the life of the given group when doing classical ethnographic research to get to know and understand their state of mind. However, since the researcher takes part in the observed group's life, it affects their life. Its disadvantage is that people usually do not behave the way they usually do unconsciously, so the researcher has an effect on the examined people's behaviour. Netnography is based on the techniques of ethnographic research, but in a special environment. While earlier cultures were meant by geographically limited groups, today people form communities and groups on the internet by computer-based communication technologies [14]. Netnography is an inline qualitative method which adapts ethnographic research techniques to analyse the communities' cultures in the digital space [10]. The methodology of netnography is continuously developing by the change of internet [13].

Nowadays, more and more people use online social pages (e.g. blogs, forums, news groups, photosharing communities), so the internet is a very important source for the researchers [2]. Consumers share their opinion on the internet websites [9], and more often people use the internet as a primary source for getting information about a product or service from other people before making their purchasing decisions.

During netnographic research publicly available online communication channels are used, so researchers observe the consumers through internet surfaces (blogs, forums, groups of social sites, etc.). The aim of the research is to understand the online consumer groups' state of mind and decisionmaking mechanism [4].

The most important advantage of this high know-how content method is that consumers tell their objective opinion in their most comfortable environment, so this method is not obtrusive. Comparing with other marketing research tools, it is less cost- and time-intensive, and it can be analysed at that time and place when and where it is appropriate for the researcher [11].

A disadvantage can be that since it is suitable only to observe online communities, it narrows down the topics and subject to be examined, so it is hard to make general conclusion for the whole society [4]. In the online space communicators form the basic population, not the total population, moreover, the socio-demographic rate of different groups differs from the national population, so we cannot produce representative results for Hungary, but it is not aim of this method. Online participants are often 
present on the internet with a nickname, so the demographic background of the person cannot be analysed [27]. Besides, it is also important for the researcher to interpret the incomplete information in order to use it in an effective way.

Netnography has been used on several fields by the researchers around the world: KOZINETS (2010) made research on coffee consumption, NELSON and OTNES (2005) analysed the news boards concerning wedding organising, in Hungary DÖRNYEI and MITEV (2010) examined the attitudes towards bio food consumption with this method.

\section{Material and method}

\subsection{Process of netnographic research}

Figure 2. shows the process of netnographic research.

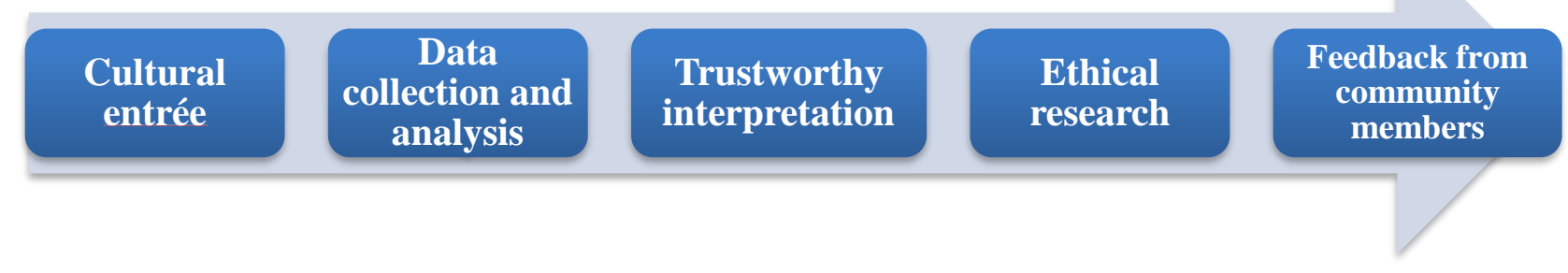

Figure 2. Process of netnographic research

(Source: own compilation based on [10] and [5])

The first step of the research is the so-called cultural entrée. In the beginning of the research a research question is defined that we would like to answer. After that we have to examine which online communication forms can contain relevant information for the research. Basically, seven online sources can be differentiated: instant messengers (e.g. Skype, MSN, chatrooms), e-mail lists, games with chatting option, blogs, search engines (e.g. Google, Yahoo!, Bing, etc.), social websites (e.g. Facebook, Instagram, Twitter, etc.) and the forums.

The level of research participation can also affect which online communication form to use. In case of the observing role, the researcher is present at the websites, but (s)he only observes the dialogues, and does not partake actively in the community. The participative-observative role is when the researcher is active in the community's life, asks questions, (s)he can direct or even provoke the online participants. The third type is the autonetnography when the researcher observes her/himself about a given topic and writes down the experience in the form of a blog, diary or any other ways [3].

The second step of the research is the data collection and analysis. After identifying the sources, relevant contents must be chosen and processed. During the analysis, roles in the online community can be identified, so groups can be defined, and as a result, even a given product or service can be developed according to their needs. 
In the course of the analysis the accurate interpretation is extremely important, so that the researcher could reflect the thoughts of the online participants without major distortions or misunderstanding. In the qualitative research the expression of trustworthiness is used instead of validity [15].

During the research the issue of ethics often arises [27]. It is important to note that if word-by-word citation is used, the permission of the author must be asked to use it later except the case when the given website's general terms and conditions dispose otherwise. Generally, most public websites operate with the term that the contents of the website can be used without permission for personal use.

According to some researchers the research report must be presented to the groups which were being observed and ask their permission if the conclusions are correct and they yield consent to publish the results $[3,5,10]$.

\subsection{Method of the primary research}

From March to October 2016 a netnographic research was being conducted in the topic of healthconscious nutrition. The base of this analysis was the research results of SZAKÁLY (2011), when he made focus group analysis to gather information about the attitudes of Hungarian inhabitants concerning their health-conscious nutrition.

This research focused on three issues:

1. How can netnographic research be applied to explore the Hungarian consumer insights in the topic of health-conscious nutrition?

2. What kind of attitudes do Hungarian online consumers have concerning health-conscious nutrition in general? (In this case attitude means the consumer's general, favourable or unfavourable evaluation, opinion about a product or a topic [1].

3. What kind of online consumer groups can be differentiated according to the explored attitudes on health-conscious nutrition?

Among the online communication forms three were chosen based on the primary research: search engines, forums, and Facebook as a social website. A stronger emphasis was put on social websites, since their detailed analysis can give several business development opportunities nowadays [20, 25]. During the online research we were only observers.

This research was being executed until the topics of comments and opinions were reoccurred and there weren't any novelty in them (principle of theoretical saturation) [7].

In this study those comments are presented which came from public websites, so no consent was needed from the online participants to publish them.

The primary key word of the research was 'health-conscious nutrition', so the analysis of the pages started according to it. The received results will be presented in the next chapter of this paper. 


\section{Results}

\subsection{Exploring attitudes by netnography}

\subsubsection{Using key words in search engines}

In this research the Google's search engine was used in Google Chrome browser. Mentioning the type of browser is also important, because search engines and browsers are optimized by different words, so the searching results and lists can vary. For the key word of 'health-conscious nutrition' 39 thousand results were found. After that we tried to search by alternative key words because of the low number of results like 'healthy nutrition' and 'healthy eating'. As a result, we can state that people use most of the time the expression of 'healthy nutrition' (962 thousand results), then 'healthy eating' (481 thousand results) instead of 'health-conscious nutrition' (39 thousand results).

After determining and refining the key words, we started to analyse the pages. Only those sites were examined where personal comments were found in response to an article. The first 40 pages were examined and among these 4 contained useful information for this research where personal comments were available. The summary of the results is the following:

- People make comments to those articles which they do not agree with.

- 'I feel sorry for the people who start to eat 'healthily' based on this guidance. Eating vegetable butter instead of butter... Why? Because it is a trans-fat and hydrogenized fat bomb, it is full of omega 6 and there is not any natural or nutritious thing in it? Let's eat potato, bread, a lot of fruit, and the obesity is guaranteed!!! It is outrageous that without any scientific background this article contains the same boring clichés.' (L. G. 27 April 2013 15:28)

- Generally, it can be stated that most people identify health-conscious nutrition and lifestyle with diet and slimming cure.

- The use of salt is also under heavy debate. It often happens that if the consumers are committed to a given product (in case of the salt it often happens with the Himalayan or Parajdi salt), they advertise it by themselves. As a voluntary expert they indoctrinate those who would think in a different way.

- 'Of course, salt is important for the human body, and it is a misbelief that the excessive salt consumption is unhealthy. It is a matter of taste. Salt contaminated with potassium is unhealthy for sure. It isn't an accident that they put it into the salt, since it is good for the pharmaceutical industry if people take blood pressure medicine regularly at the age of 40-50. www.parajdiso.com' (István V., 29 October 2012 15:20)

- 'Salt is a very simple thing for us, but still it is essential in our life, since not only the human body needs it, but it is also an element of the Earth. However, I know that humans pollute the seas from where we get the salt, so it is very important to clean it properly before putting it on our table. My children usually use a lot of salt in the meals, but I know that it is not too healthy. I found the Himalayan salt which gives the same taste with smaller amount, it makes the food healthier and it has several positive effects on out body. I read about it a lot and I use it in cooking with pleasure. www.himalajaso.hu' (Krisztina Á., 8 August 2012 10:53)

- 'I also use this salt, its sodium content is very high and its potassium content is very low, that's why it is good $-($ it is very healthy if we put a lot of salt in the dishes.' (Tormás T., 26 April 2013 21:22) 
- Sugar use also often arises among the comments. Many people think that it is healthy if they eliminate the sugar totally, and they use some artificial sweeteners instead of it. In this context the nutrition of children also occurs, since a lot of parents believe that a child does not need any sugar or extra sweetening, so until the child is small and stays at home with the mother, (s)he does not get any sweets or sugary dish. However, when the child gets into the community (crèche, kindergarten), the parent cannot affect what the child eats daytime.

- 'My family looked at me as a UFO, because my 14-month old child is not allowed to eat chocolate even at Christmas either. I make yoghurt (natural yoghurt + fruit + birch sugar), the child does not know what the milk snack or cereal is, and I went out of my mind when the breakfast was milk with chocolate cereals in the crèche. (Doctors do not suggest drinking milk until the age of three.) S(he) has never eaten creamed cottage cheese from the shop, but now my child became very picky... * I am insulin resistant with strict diet, but my child does not want to eat salad and whole wheat stuff. But I think that healthy lifestyle is more expensive than the 'conventional' if I look at the price of a normal yoghurt and a quality handicraft one, there are significant differences...' (Virág K., 4 February 2016 20:53)

- There are heavy debates on dairy products. Some people think that an adult does not need any milk, while others doubt it heavily. Diet-makers are often worried about eating cheese at all, since it has a high fat content.

- 'This milk thing is a real bullshit... human body does NOT need any milk at all, moreover, it is even harmful... end of story.' (Patrícia V., 16 August 2013 18:35)

- 'That's all junk, because the milk is really important for the body... it is even strengthens the bones... And it is very healthy!!' (Fanni P., 20 November 2013 18:35)

- Concerning the consumption of butter and vegetable butter, we can differ two groups: there are some people who prefer the butter because of its naturalness, while others campaign for the vegetable butter (e.g. who learned chemistry and know the exact chemical process of the production).

- II read it several times that vegetable butter is not good, because its production is the result of a chemical process. For me, it is logical. Butter is made of milk fat mechanically, which does not harm the ingredients.' (Ágnes O., 5 November 2013 17:14)

- 'It is not so trues, because there are differences among the vegetable butters. Vegetable butter is said to be unhealthy, because there are such materials (trans-isomers of oils) that are not present in the nature, and our body does not produce such enzymes which could degrade them. But the quality of vegetable butter (significant difference in prices) shows the rate of harmful compounds. Vegetable butter is made of plants, butter is animal origin fat. But the vegetable one is much healthier, but the normal butter increases the cholesterol level as well, so I think it is worth buying an expensive but better quality vegetable butter than butter. But this is only my point of view. (-) Have a nice day! (a student at chemistry)' (Angelika P. 20 June 2015 16:57)

\subsubsection{Results of forum portals}

As the next step of the research, we were looking for contents in the topic of 'health-conscious nutrition' on forum portals. The following forum portals were involved in this examination: www.nlcafe.hu/forum, forum.index.hu, forum.origo.hu, www.hoxa.hu, www.noiportal.hu, www.csaladinet.hu/forum. On the forum pages we were searching for consumer opinions in the existing forum topics. However, we realized that concerning the health-conscious nutrition, we did not find any forum topic with this title. But in the content of the forum topics this expression appeared. We 
can state that forumers use the expression of 'healthy nutrition' and 'healthy eating' instead of healthconscious nutrition. Another problem arises with the forum portals that regular comments can only be found until 2013-2014, after that it is very rare, so if we would like to get up-to-date information from the consumers for the research, forums cannot be considered as proper sources.

To sum up, it can be stated that while in previous netnographic researches forums were used as primary sources, nowadays these surfaces are "dying out". This may be due to the social websites which online participants started to use to share their opinion instead of them.

\subsubsection{Results of searching on Facebook}

After the first two online sources, the research was continued on the most popular social website. Such closed/public groups, communities or pages were being looked for which were dealing with the topic of health-conscious nutrition. In most closed groups it is not allowed to place advertisements or links for marketing purpose. Comments and posts can be observed and retrieved, and besides, general questions can be asked on experience and opinion about a certain product or service. By searching with the key words, we found one page and 4 closed groups to observe, which has more than 55 thousand members and likers. Our observations gave the following results:

- Most posts are about what they cooked. They presented such dishes that they think to be healthy and they also attached pictures to the posts. In short period of time the active members comment to the posts and asked for recipes and advice about a special ingredient if they had not met it before.

- 'This gingerbread was made by the recipe I found on the page of Clean eating. Excellent, soft. Thanks C.E. (-)' (Lotte L. 11 október 2016)

- 'Darlings! Today's menu: Roasted chicken breast and broccoli. With lactose-free sour cream and eggs. Himalyan salt and freshly grounded pepper. For dinner spicy lactose-free cottage cheese with bryndza. Only with red pepper. Today protein bombing! ;-) I hope I could give you good ideas! @-)Good appetite for all!' (Szilvia F. 12 September 2016.)

- 'Hi, how do you prepare sweet potato if you want to eat it as French fries? Until now we fried it in oil, but I would like to prepare it in a healthier way. Thanks in advance $)($ at the same time if you have recipe for a healthy dip, I would appreciate that (-))' (Julie F. 30 July 2016)

- People often ask advice from each other about a product, for example:

$\circ \quad$ With which flour could they substitute durum flour that is also healthy?

'Hi -) Can anyone help me which flour to use instead of durum flour and in what rate? And could you tell me a place in Budapest where I can buy durum flour? :-) Thanks for your help in advance' (Mercédesz P. 2 May 2016)

'Hi all! What kind of flour do you use? I would need a good carrot cake recipe not for a lot of money. Ideas? And why do you buy it? Thanks' (Gina N. 6 July 2016)

- What others train?

'Hello, I don't want to ask about food, but I would like to ask you how do you train? How much time did it take to notice some change on yourselves? $\odot$ '(Claudia B. 10 April 2016) 
○ Can they recommend milk-, egg-, gluten-, corn-, vegetable milk- and yeast-free bread recipe?

'I would like to ask some help! I hope somebody has a great recipe! - I am a young woman with a lot of food intolerance and I am looking for a bread recipe -)it cannot contain: gluten, corn, egg, milk derivatives, vegetable ilk, yeast... Until now I have used everything-free bread flour mix - it was working with sodium bicarbonate, but now I cannot eat chick-peas which the flour mix contains! -) Now I'm trying the combination of millet-buckwheat flour and bamboo fibre... but something is not working in the recipe since it has a horrible by-taste (however I make it the same way every time). I know: I shouldn't eat bread - but in the morning I need $30 \mathrm{~g}$ carbohydrate, so... (-) If you have an idea and share your great recipe with me, I will be very grateful!' (Eszti V., 10 April 2016)

○ What kind of experience others have concerning carbohydrate-. gluten-, sugar- and fatfree noodles?

'Do you know the No Carb Noodles? Opinion? I got it.' (Moncsi B. 28 March 2016)

'What is your opinion about this? Noodles from red lens (Ingredients: red lens, nothing else)' (Katalin N. 3 August 2016)

- People who think that they eat in a health-conscious way, they are often on a gluten-, and sugarfree diet, however, their health status would not require it.

- 'Well, this was a phenomenal idea from myself: oat sponge cake with strawberry foam! Absolutely dietetic, vegan, paleotic, so it is edible aaaand deliciooouus!!!' (Hajnalka H. 9 May 2016)

- Consumers often look for complex nutritional- and lifestyle programs, which they can commit to. Such as Clean Eating, Norbi Update, Alakreform.

- II would like to ask some advice, info, or who has experience on it. What do you know or hear about the Metabolic-type nutrition? How reliable is it? I'm getting more and more links concerning this topic. And it has caught my interest. Thanks.' (Alexander Cs. 27 October 2016)

- A lot of people who train regularly, use powders when preparing their meals, which they think to be healthy: fibre mix, protein powders, flavoured protein powders, etc.

- 'Very quick floating islands with protein. Real, thick and creamy... from 2 eggs, 3 dl milk (it can also be rice milk) and 1 portion vanilla protein." (Ildikó K. 20 April 2016)

- People often use and recommend unique materials considered to be healthier, such as chia seed, tapioca pearls, vegetable milk (different seed milks), etc.

- 'Strawberry porridge with a lot of strawberries $*$, chia seed, dried cherries, nuts and scitec peanut butter to start the daily training with a lot of energy.' (Evelin A. 4 June 2016)

- 'Protein chia pudding with strawberry sauce. After mixing the strawberry sauce, it became too liquid, so I put some Psyllium Husk into it, which made it jellier.' (Ildikó Sz. 20 April 2016)

\subsection{Identifying online consumer groups according to the netnographic research}


KOZINETS (2010) separated the online participants into four groups by their activity and the strength of their strength of communal ties to the online communities: newbies, minglers, insiders and devotees. Newbies are not really interested in the consumption of a given product and their tie is low to the online community. Minglers have strong ties to the online group, but their consumption activity is low. Devotees have very high consumption activity, however their ties are really weak to the online community. Insiders are active consumers who are tied very strongly to the online community as well. In case of the netnographic research we can state that the groups of devotees and insiders are the most important for the researchers, since we can get the most information from them.

In the course of our research we identified the following groups concerning health-conscious nutrition in the online communities (Figure 3.):

1. The meddlesome: people who join several groups and like a lot of pages which they are interested in. They are looking for such comments where they can tell their opinion considered to be true, but they do not participate in the conversation for long time, they communicate briefly, after that they leave. Generally, they do not quit the group, but they are not active comment makers.

2. The quack: people who would like to change something in their nutrition habits, but they are not really determined and they are looking for opportunities. They have usually strong ties to the groups, because they like if they belong somewhere, but they are not enough persistent on a longer term to maintain a new nutrition mode.

3. The inquisitive: people in this group are deeply committed to a nutrition mode and they can keep its principles even in a longer term. Their tie to the online groups is weak, so they only visit the group/page if they have a question to be answered.

4. The dumb: online participants who are committed to some nutrition type considered to be healthy, but they do not tell their opinion in the online communities rather read what they are interested in. They do not initiate the communication, but their consumption activity is quite high. Considering the number of people they are the biggest group, actually they mean the crowd.

5. The self-appointed expert: people who know a lot about health-conscious nutrition in their opinion and they are very strongly tied to the online community, often step up as selfappointed experts. They are the ones who communicate in a very determined and open way, tell their opinions, experiences in the community and give advice for those who ask questions. They react intensively if they do not agree with something. If they are satisfied with a product and committed to it by $100 \%$, they feel that it is their mission to recommend it to others as well.

6. The real expert: online participants who are ideals for others, usually sportsmen, personal trainers, who have several years of expertise concerning health-conscious nutrition and lifestyle. In many cases they establish an own group or webpage on the social sites with a general name for which they recruit followers. In most cases they do not use their own name 
for the group, because it would be more difficult to find followers for that, so this way they reach a wider circle of people.

7. The advertiser: people of this group want to advertise their own products or their task is to advertise a certain product. they often use fake names and place advertisements in the groups of online communities. During the research we have found several advertisements, for example slimming pectin, Himalayan salt, and other slimming dietary supplements. In Facebook groups it is forbidden to place such advertisements, otherwise these participants will be stroke off the groups. On the forum portals and websites these comments or posts are not deleted. Of course, we filtered these advertisements, since they would exclude our results as well.

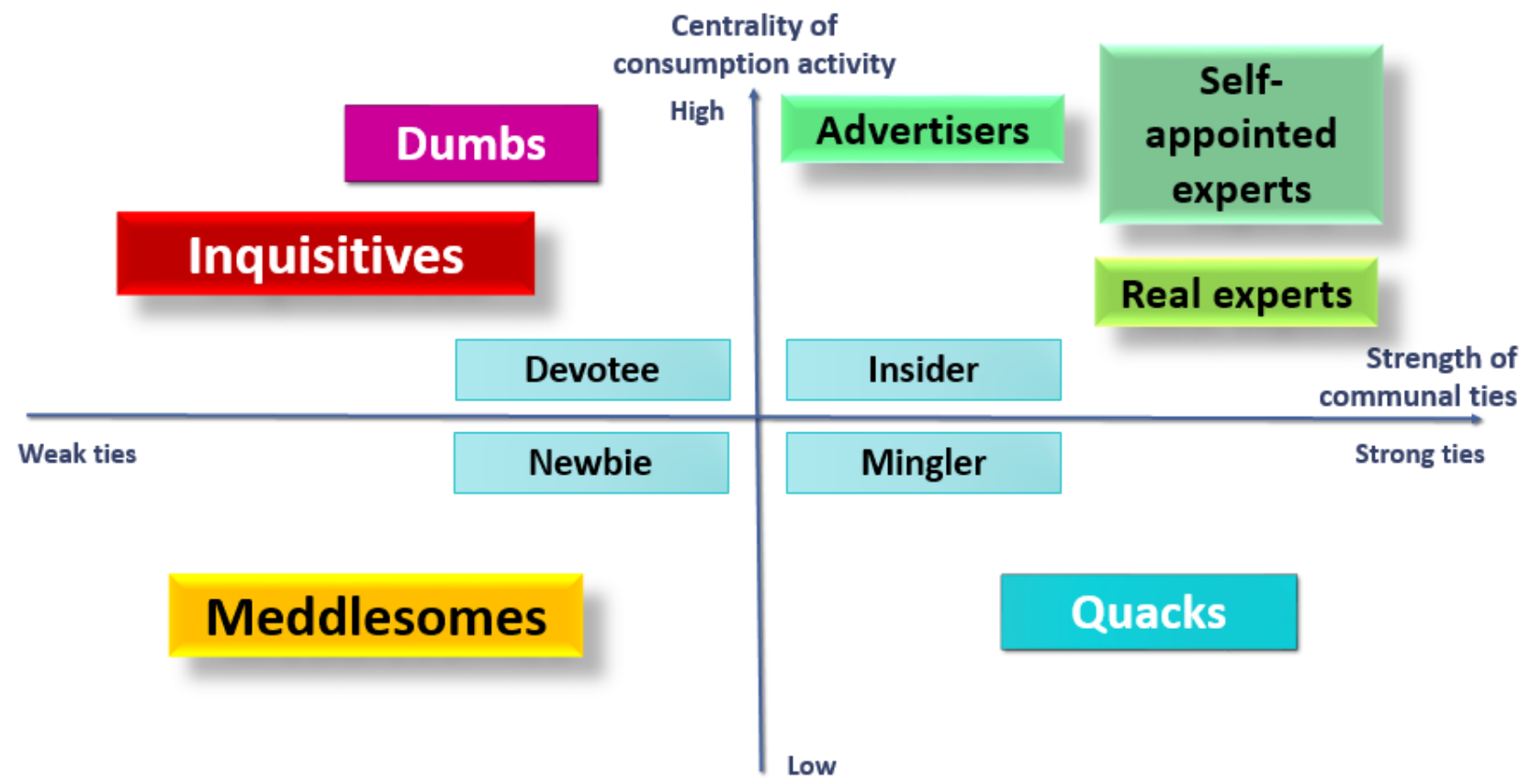

Figure 3. Online consumer groups concerning the topic of health-conscious nutrition

(Source: adaptation of [10] and [5] results supplemented with own results)

Some of the above-mentioned groups are overlapping the groups described by DÖRNYEI - MITEV (2010) who explored the attitudes of organic food consumers by online 'armchair' ethnography. They defined the following groups: self-appointed experts, real experts, advertisers, questioners, bunglers. However, it has to be emphasized that the group of 'dumbs' has never appeared before. In our opinion, this group has the highest number of members, and among them we can also find people who are opinion leaders offline (in their everyday social lives). But to prove this, further research is needed to be executed in the future.

\section{Conclusions}

Conclusions made by the research results will be presented according to the sequence of research questions. 
Research question 1. How can netnographic research be applied to explore the Hungarian consumer insights in the topic of health-conscious nutrition?

- In the beginning of the research key words have to be defined exactly by which we would like to search. First of all, it has to be checked which form is used most frequently on a daily basis. In this research it could be stated that people use most of the time the expression of 'healthy nutrition' (962 thousand results), then 'healthy eating' (481 thousand results) instead of 'health-conscious nutrition' (39 thousand results).

- Searching on forum portals does not give up-to-date information from the consumers for the research since regular comments can only be found until 2013-2014, after that it is very rare. In our opinion it is due to the fact that nowadays people use the different groups/pages of social websites (primarily Facebook) to share their opinion or to ask advice.

- Observing Facebook groups and pages gives the most information from customers. In most cases, it is also possible to analyse the demographic background of a person.

- Netnographic research can supplement the classical market research techniques quite well, since such consumer insights can be explored which would be more difficult to get to know so deeply otherwise. Before starting the netnographic research we can do an exploring focus group analysis, even for defining the key words. After executing the netnographic research, another focus group analysis can be used to refine the results. We can also use it to check if the consumers' opinion was interpreted in a trustworthy way. It was also concluded by MILES and HUBERMAN (1994), SHERRY (2008) (in: WEIJO et al., 2014) and SIMPSON (2006) as well, because they also stated that if independent measurements are made, they verify each other which increases validity.

Research question 2. What kind of attitudes do Hungarian online consumers have concerning healthconscious nutrition in general?

- People make comments to those articles which they do not agree with.

- Generally, it can be stated that most people identify health-conscious nutrition and lifestyle with diet and slimming cure.

- People who think that they eat in a health-conscious way, they are often on a diet (gluten-, and sugar-free), however, their health status would not require it.

- Many people think that it is healthy if they eliminate the sugar totally, and they use some artificial sweeteners instead of it.

- It often happens that if the consumers are committed to a given product (in case of the salt it often happens with the Himalayan or Parajdi salt), they advertise it by themselves. As a self-appointed expert they indoctrinate those who would think in a different way.

- Some people think that an adult does not need any milk, while others doubt it heavily. Diet-makers are often worried about eating cheese at all, since it has a high fat content.

- Consumers often look for complex nutritional- and lifestyle programs, which they can commit to.

Research question 3. What kind of online consumer groups can be differentiated according to the explored attitudes on health-conscious nutrition?

- Online participants have been separated into seven groups concerning health-conscious nutrition: meddlesomes, quacks, inquisitives, dumbs, self-appointed experts, real experts and advertisers.

- Among these, the group of 'dumbs' has never appeared before. In our opinion, this group has the highest number of members, and among them we can also find people who are opinion leaders 
offline (in their everyday social lives). But to prove this, further research is needed to be executed in the future.

\section{Summary}

In the last two decades the fast penetration of the internet has had more significant effect on consumer behaviour. Nowadays, many people use the internet when making purchase decisions and primarily others' opinion affect them which product or service to use. It also encourages the market researchers to apply such methods which bring them closer to the consumers to get to know their attitudes without taking them out from their natural environment. Netnography is a method like this. Nevertheless, it is important to emphasize that netnographic research primarily supplements and not substitutes the classical market research methods by learning such consumer insights which would be more difficult with other techniques.

\section{References}

[1] I. Ajzen - M. Fischbein (1980): Understanding attitudes and predicting social behaviour, Englewood Cliffs, NJ: Prentice Hall, 1-278.

[2] G. M. Bowler (2010): Netnography: A method specifically designed to study cultures and communities online, The Qualitative Report, Vol. 15. Nr. 5. 1270-1275.

[3] K. M. Dewalt - B. R. Dewalt (2002): Participant Observation: A Guide for Fieldworkers, Walnut Creek, CA: AltaMira Press.

[4] K. Dörnyei (2008): Bioélelmiszer fogyasztási szokások, Marketing \& Menedzsment, 2008/4. $34-42$.

[5] K. Dörnyei - A. Mitev (2010): Netnográfia avagy on-line karosszék-etnográfia a marketingkutatásban, Vezetéstudomány, 2010. 4. szám, 55-68.

[6] A. Füzi (2013): A nyílt innováció egyik eszköze: Living Lab? In: Inzelt A. - Bajmóczi Z.: Innovációs rendszerek. Szereplők, kapcsolatok és intézmények. JATEPress, Szeged, 180195.

[7] B.G. Glaser - A.L. Strauss (1967): The Discovery of Grounded Theory, Aldine, Chicago

[8] A. K. Gupta - S. P. Raj - D. Wilemon (1986): A Model for Studying R\&D. Marketing Interface in the Product Innovation Process. Journal of Marketing, Vol. 50, No. 2 (Apr., 1986), pp. 717.

[9] C. Iglesias (2007) Etnografia Virtual, Revista AMAI, v.1., n.4. 62.

[10] R. V. Kozinets (2002): The Field Behind the Screen: Using Netnography for Marketing Research in Online Communities, Journal of Marketing Research, 39 (February), 61-72.

[11] R. V. Kozinets (2006): Click to Connect: Netnography and Tribal Advertising, Journal of Advertising Research, September 2006, 279-288. 
[12] R. V. Kozinets (2010): Netnography. Doing ethnographic research online, Thousand Oaks, CA: Sage Publications.

[13] R. V. Kozinets (2012): Marketing Netnography: Prol/ot(ulgat)ing a New Research Method, Methodological Innovations Online, 7(1), 37-45.

[14] D. Kulavuz-Onal - C. Vásquez (2013): Reconceptualising fieldwork in a netnography of an online community of English teachers, Etnography and Education, Vol. 8, No. 2, 224-238.

[15] Y. S. Lincoln - E. G. Guba (1985): Naturalistic Inquiry, Beverly Hills, CA: Sage Publications.

[16] M. R. Nelson - C. C. Otnes (2005): Exploring cross-cultural ambivalence: a netnography of intercultural wedding message boards, Journal of Business Research, 58, 89-95.

[17] M. B. Miles - A. M. Huberman (1994): Qualitative Data Analysis, Sage Publications.

[18] S. Myers - D. Marquis (1969): Successful Industrial Innovation. Washington, DC: National Science Foundation.

[19] I. Piskóti (2006): Az innovációmarketing gyakorlati megoldásai. In: Innovációmarketing (Szerk.: Vágási M. - Piskóti I. - Buzás N.). Akadémiai Kiadó, Budapest, 129-162.

[20] S. Quinton - D. Wilson (2016): Tensions and ties in social media networks: Towards a model of understanding business relationship development and performance enhancement through the use of LinkedIn, Industrial Marketing Management, Vol. 54, 15-24.

[21] K. Schwartz (2004): Schwartz K. (2004): Az integrációorientált innovációs folyamatok infokommunikációs kihívásai. GIKOF Journal 3 (5) 37-43.

[22] L. S. Simpson (2006): The value in combining netnography with traditional research techniques, American Marketing Association, Summer 2006, 193-200.

[23] J. F. Sherry (2008): The ethnographer's apprentice: Trying consumer culture from outside in, Journal of Business Ethics, 80, 85-95.

[24] Z. Szakály (2011): Táplálkozásmarketing, Budapest: Mezőgazda Kiadó, 2011. 216 p.

[25] W. Y. C. Wang - D. J. Pauleen - T. Zhang (2016): How social media applications affect B2B communication and improve business performance in SMEs, Industrial Marketing Management, Vol. 54, 4-14.

[26] H. Weijo - J. Hietanen - P. Mattila (2014): New insigths into online consumption communities and netnography, Journal of Business Research, 67, 2072-2078.

[27] J. Xun - J. Reynolds (2010): Applying netnography to market research: The case of the online forum, Journal of Targeting, Measurement and Analysis for Marketing, Vol. 18, 1, 17 31.

[28] G. Zaltman - R. Duncan - J. Holbek (1973): Innovation and Organizations. New York, Wiley. 